\title{
PENGHASILAN KOMPREHENSIF LAIN PERUSAHAAN SEKTOR JASA KEUANGAN DI INDONESIA: SEBUAH STUDI CONTENT ANALYSIS
}

\author{
Rohmat Suryanto $^{1 *}$, Amrie Firmansyah ${ }^{2)}$ \\ ${ }^{1}$ Jurusan Akuntansi, Politeknik Keuangan Negara STAN \\ email: rohmat.suryanto@yahoo.com \\ 2 Jurusan Akuntansi, Politeknik Keuangan Negara STAN \\ email: amrie.firmansyah@gmail.com
}

\begin{abstract}
This study aims to review other comprehensive income information for companies in Indonesia. The method used in this research is to use qualitative methods with content analysis techniques. This study uses data from financial services sector companies listed on the Indonesia Stock Exchange (IDX) from 2012 to 2018. Company data in this study are sourced from www.idnfinancials.com. The data used is data of companies listed before January 1, 2012, with the total company data used in this study are 34 companies. This study concludes that the most widely reported component is the gain and loss on remeasurement of financial assets as available for sale of $40.28 \%$. Meanwhile, companies that report profit and loss components on the remeasurement of financial assets as "available for sale" were $71.43 \%$. Based on this research, companies in the financial services sector should present other comprehensive income components in their financial reports to be more comfortable for stakeholders to understand.
\end{abstract}

Keywords: other comprehensive income, financial services, IFRS adoption.

\section{ABSTRAK}

Penelitian ini bertujuan untuk mengulas informasi penghasilan komprehensif lain perusahaan di Indonesia. Metode yang akan digunakan dalam penelitian ini adalah menggunakan metode kualitatif dengan teknik analisis isi. Penelitian ini menggunakan data perusahaan sektor jasa keuangan yang terdaftar di Bursa Efek Indonesia (BEI) periode tahun 2012 sampai dengan tahun 2018. Data perusahaan dalam penelitian ini bersumber www.idnfinancials.com. Data yang digunakan adalah data perusahaan yang listed sebelum tanggal 1 Januari 2012 dengan jumlah data perusahaan yang digunakan dalam penelitian ini adalah 34 perusahaan. Penelitian ini menyimpulkan bahwa komponen yang paling banyak dilaporkan adalah keuntungan dan kerugian atas pengukuran kembali aset keuangan sebagai tersedia untuk dijual sebesar $40,28 \%$. Sementara itu, perusahaan yang melaporkan komponen keuntungan dan kerugian atas pengukuran kembali aset keuangan sebagai 'tersedia untuk dijual' sebanyak $71,43 \%$. Berdasarkan penelitian ini, perusahaan sektor jasa keuangan sebaiknya menyajikan komponen penghasilan komprehensif lain dalam laporan keuangan dengan jelas agar lebih mudah dipahami oleh pemangku kepentingan.

Kata Kunci: penghasilan komprehensif lain, jasa keuangan, adopsi IFRS 


\section{PENDAHULAN}

Perusahaan menyusun laporan keuangan untuk menghasilkan informasi yang relevan dan andal menurut standar akuntansi (Martani et al., 2016). Di Indonesia Pernyataan Standar Akuntansi Keuangan (PSAK) diadopsi dari International Financial Reporting Standard (IFRS) dan telah dimulai sejak tahun 2008. Proses konvergensi IFRS telah selesai pada tahun 2012 dan mulai diimplementasikan secara bertahap (Astuti \& Sulistyowati, 2017). Selanjutnya, pada tahun 2015 Dewan Standar Ikatan Akuntan Indonesia (DSAK IAI) telah berhasil meminimalkan kesenjangan antara tanggal efektif standar IFRS dengan PSAK menjadi satu tahun (Otoritas Jasa Keuangan, 2016). Konvergensi IFRS tersebut merupakan salah satu kesepakatan pemerintah Indonesia sebagai anggota G20 untuk meningkatkan transparansi, akuntabilitas, dan globalisasi laporan keuangan (Suyatmini \& Sheilla, 2014). Selain itu, kebutuhan akan konvergensi IFRS juga diperkuat dengan diberlakukannya ketentuan Masyarakat Ekonomi ASEAN (MEA) mulai tahun 2015 di mana Indonesia juga merupakan anggota ASEAN (Berita Satu, 2013). IFRS diterapkan dengan harapan kualitas laporan keuangan dapat meningkat dan dapat membantu pengguna dalam mengambil keputusan.

Perubahan penerapan standar akuntansi keuangan menyebabkan perubahan penyajian laporan keuangan perusahaan di Indonesia. Sebelum dilakukan konvergensi IFRS, komponen laporan keuangan perusahaan meliputi Neraca, Laporan Laba Rugi, Laporan Perubahan Modal, Laporan Arus Kas, dan Catatan Atas Laporan Keuangan (CaLK). Setelah dilakukan konvergensi IFRS, komponen laporan keuangan perusahaan meliputi Laporan Posisi Keuangan, Laporan Laba Rugi dan Penghasilan Komprehensif Lain, Laporan Perubahan Ekuitas, Laporan Arus Kas, dan
Catatan Atas Laporan Keuangan (CaLK) (Pardede, 2016).

Berdasarkan kerangka dasar penyusunan dan penyajian laporan keuangan disebutkan bahwa laporan laba rugi diperlukan untuk menilai perubahan potensial sumber daya ekonomi yang mungkin dikendalikan di masa depan (Ikatan Akuntansi Indonesia, 2014). Kieso et al. (2018) menyatakan, laporan laba rugi dapat membantu pengguna laporan keuangan untuk memprediksi arus kas dimasa depan dengan beberapa cara antara lain, mengevaluasi kinerja masa lalu perusahaan, memberikan pijakan untuk memprediksi kinerja masa depan, dan membantu menilai ketidakpastian atau risiko dalam mencapai arus kas masa depan. Berdasarkan standar sebelumnya yang mengacu pada Generally Accepted Accounting Principles (US-GAAP) informasi terkait kinerja perusahaan disajikan dalam laporan laba rugi dan komponen penghasilan komprehensif lain disajikan pada pos penghasilan lain-lain dan/atau beban lain-lain (Mustaip, 2015). Setelah dilakukan konvergensi, penyajian laporan terkait laba rugi mengalami beberapa perubahan. Perubahan yang cukup menonjol terlihat pada penyajian penghasilan komprehensif lain atau Other Comprehensive Income (OCI) tersendiri dalam laporan keuangan terpisah atau digabungkan dengan laporan laba rugi (Wahyu \& Praptoyo, 2014).

Penyajian laba komprehensif lain atau OCI dalam laporan laba rugi dapat memberikan informasi tambahan bagi pengguna laporan keuangan terkait kinerja perusahaan di luar operasi normal. Menurut Biswan (2019) item laba komprehensif lain meliputi perubahan ekuitas selama suatu periode tidak termasuk investasi oleh pemilik maupun distribusi kepada pemilik. Perubahan tersebut dapat terjadi misalnya karena perubahan nilai wajar (fair value) akibat pengaruh pasar. Oleh karena itu 
keberlangsungan operasional perusahaan dapat terlihat melalui pengungkapan nilai wajar dalam pos OCI. Penelitian sebelumnya oleh Mustaip (2015) juga menyimpulkan bahwa informasi terkait OCI dapat digunakan sebagai informasi dalam menganalisis kinerja suatu perusahaan sehingga berkontribusi pada proses pengambilan keputusan oleh pengguna laporan keuangan.

Komponen penghasilan komprehensif lain sesuai PSAK 1 (2015) tentang Penyajian Laporan Keuangan mencakup perubahan dalam surplus revaluasi yang mengacu pada PSAK 16tentang Aset Tetap dan PSAK 19 tentang Aset Tak Berwujud, pengukuran kembali program imbalan pasti yang mengacu pada PSAK 24 tentang Imbalan Kerja, keuntungan dan kerugian yang timbul dari penjabaran laporan keuangan dari kegiatan usaha luar negeri yang mengacu pada PSAK 10 tentang Pengaruh Perubahan Kurs Valuta Asing, keuntungan dan kerugian dari pengukuran kembali aset keuangan sebagai tersedia untuk dijual, dan bagian efektif dari keuntungan dan kerugian instrumen lindung nilai dalam rangka lindung nilai arus kas yang mengacu pada PSAK 55 tentang Instrumen Keuangan: Pengakuan dan Pengukuran (IAI, 2014).

Sejalan dengan perubahan PSAK pada tahun 2012 Badan Pengawas Pasar Modal dan Lembaga Keuangan (Bapepam dan LK) yang kini menjadi Otoritas Jasa Keuangan (OJK), menerbitkan keputusan nomor Kep-347/BL/2012 yang mewajibkan emiten dan perusahaan publik untuk melaporkan laporan keuangannya berdasarkan standar terkini. Regulasi ini berdampak pada perusahaan di Indonesia terutama terhadap perusahaan yang terdaftar di Bursa Efek Indonesia (BEI) salah satunya perusahaan sektor perbankan. Perusahaan perbankan, termasuk yang cukup banyak mengalami dampak perubahan baik pada internal perusahaan maupun dari eksternal seperti Bank Indonesia sebagai regulator
(Martani, 2011). Menurut Pratiwi \& Tesniwati (2013) penerapan PSAK berbasis IFRS dapat membuat praktik Good Corporate Governance (GCG) pada bank umum di Indonesia meningkat. Hal tersebut terlihat dari karakteristik kualitatif laporan keuangannya yang lebih baik. Dengan demikian, penerapan PSAK berbasis IFRS berdampak positif terhadap laporan keuangan sektor perbankan.

Penelitian Wahyu \& Praptoyo (2014) mengulas lima komponen pos OCI dan tiga cara penyajian OCI perusahaan sektor manufaktur pada tahun 2011-2013. Penelitian tersebut menyimpulkan bahwa pada praktiknya komponen penghasilan komprehensif lain disajikan dalam laba (rugi) periode dan laba (rugi) komprehensif gabungan. Mustaip (2015) membahas OCI pada 166 perusahaan yang terdaftar di BEI dari 459 perusahaan yang terdaftar tahun 2012-2013. Penelitian tersebut menyimpulkan bahwa dari sampel yang diambil, perusahaan telah menerapkan IFRS sehubungan dengan pos OCI. Penelitian Kurniawan (2017) membahas OCI pada sektor aneka industri untuk menginvestigasi ada tidaknya perbedaan penyajian pos OCI pada 42 perusahaan dalam sektor tersebut. Hasil penelitian tersebut menunjukkan bahwa terdapat perbedaan penyajian pada lima komponen OCI dan tidak ada perbedaan penyajian pada dua komponen OCI. Sementara itu Sidantha et al. (2018) juga menginvestigasi ada tidaknya perbedaan penyajian pos OCI namun pada sektor berbeda yaitu infrastruktur dan utilitas dengan sampel sebanyak 48 perusahaan. Hasil penelitian tersebut menyimpulkan terdapat tiga komponen OCI yang paling sering disajikan dan terdapat perbedaan penyajian pada komponen selisih kurs. Selanjutnya, penelitian oleh Santoso et al. (2017) membahas penyajian OCI pada industri keuangan 2012-2015. Hasil penelitian tersebut menyimpulkan terdapat perbedaan penyajian untuk empat komponen OCI pada laporan laba rugi dan penghasilan komprehensif lain, lalu untuk 
dua komponen OCI tidak ada perbedaan penyajian dalam laporan laba rugi dan penghasilan komprehensif lain. Sementara itu, untuk satu komponen OCI tidak dapat disimpulkan karena seluruh sampel tidak menyajikan dalam laporan keuangannya.

Berbeda dengan penelitian sebelumnya, penelitian ini bertujuan untuk mengulas dan menganalisis penyajian OCI dengan rentang waktu yang lebih panjang untuk mengetahui tren penyajian masing-masing komponen pos OCI dalam laporan keuangan khususnya sektor jasa keuangan. Adapun sektor jasa keuangan digunakan dalam penelitian ini karena sektor ini merupakan sektor strategis yang mengumpulkan dana dari masyarakat (Mahendra \& Firmansyah, 2019). Selain itu, sektor ini juga tidak luput dari pengaruh konvergensi PSAK terhadap IFRS (Martani, 2011). Menurut Rosyadi \& Anggraita (2014) sub sektor perbankan yang merupakan salah satu sektor keuangan merupakan industri yang memiliki risiko tinggi terpapar perubahan nilai wajar, karena perusahaan sektor keuangan cenderung sering berinvestasi pada instrumen keuangan. Oleh karena itu, informasi perubahan nilai wajar ini perlu disajikan dalam laporan laba rugi tidak hanya diungkapkan dalam CaLK. Dengan demikian, informasi tersebut dapat mempermudah investor selaku pemilik modal dalam mengambil keputusan. Selain itu, penelitian ini diharapkan dapat memberikan kontribusi dalam ulasan OCI mengingat masih belum banyak referensi yang membahas terkait hal ini. Bahasan tersebut cukup penting untuk dilakukan karena dapat membantu pengguna laporan keuangan untuk lebih memahami laporan keuangan khususnya komponen OCI.

\section{KAJIAN LITERATUR}

Laporan laba rugi komprehensif merupakan salah satu komponen laporan keuangan yang harus dibuat perusahaan untuk mengukur kinerja perusahaan untuk periode tertentu. Sejak diberlakukannya revisi atas Pernyataan Standar Akuntansi
Keuangan (PSAK) mulai tahun 2012, terdapat tambahan pos penghasilan komprehensif lain (OCI) pada laporan laba rugi. Penambahan pos OCI pada laporan laba rugi dapat memberikan informasi kepada pengguna laporan keuangan terkait kinerja perusahaan di luar kegiatan operasional normal perusahaan terkait dengan penggunaan nilai wajar (Mustaip, 2015). Dampak dari penggunaan nilai wajar tersebut adalah meningkatnya relevansi laporan keuangan yang disampaikan oleh perusahaan (Suyatmini \& Sheilla FN, 2014).

Laporan laba rugi komprehensif terdiri atas keuntungan dan kerugian baik yang telah direalisasikan maupun keuntungan dan kerugian yang belum direalisasikan. Keuntungan dan kerugian yang telah direalisasikan disajikan dalam laporan laba rugi. Sedangkan keuntungan dan kerugian yang belum direalisasikan disajikan dalam penghasilan komprehensif lain (Adhawati, 2019). Laporan laba rugi komprehensif adalah laporan yang digunakan untuk mengukur tingkat keberhasilan kinerja suatu perusahaan untuk periode tertentu yang dapat digunakan untuk memprediksi dan menilai jumlah dan waktu terhadap ketidakpastian arus kas masa yang akan datang. Laba rugi komprehensif merupakan perubahan ekuitas perusahaan selain yang berkaitan dengan transaksi kepada pemilik selama satu periode yang bersumber baik dari transaksi maupun peristiwa lain. Dua komponen utama dalam laba rugi komprehensif adalah laba rugi dan pendapatan komprehensif lain. Laba rugi adalah total pendapatan (revenues) dikurangi beban-beban selain komponen pendapatan komprehensif lain, sedangkan pendapatan komprehensif meliputi pos-pos pendapatan dan beban yang tidak diakui dalam laba rugi sebagaimana disyaratkan oleh SAK lainnya (Martani et al., 2016).

Menurut Kieso et al. (2018) pendapatan adalah arus masuk atau peningkatan lain dari aset suatu entitas atau penyelesaian 
kewajibannya (atau kombinasi keduanya) selama periode pengiriman atau produksi barang, menghasilkan layanan, atau kegiatan lain yang merupakan operasi utama atau pusat entitas yang sedang berlangsung. Di samping itu, pengertian penghasilan komprehensif adalah perubahan ekuitas (aset bersih) suatu entitas selama suatu periode transaksi dan peristiwa lainnya termasuk semua perubahan ekuitas selama periode selain yang dihasilkan dari investasi oleh pemilik dan distribusi kepada pemilik. Selanjutnya, penghasilan komprehensif lain semua keuntungan dan kerugian di luar laba bersih yang mempengaruhi ekuitas.

Menurut Biswan \& Mahrus (2019) pendapatan (income) adalah kenaikan manfaat ekonomis pada periode tertentu berupa kenaikan aset/arus masuk atau penurunan liabilitas yang akan meningkatkan ekuitas selain dari kontribusi pemegang saham. Perusahaan yang menerapkan IFRS lazimnya melaporkan laba rugi yang lengkap atau komprehensif tidak berhenti pada laba bersih. Laba rugi komprehensif didapatkan setelah menambahkan laba bersih dengan penghasilan komprehensif lain yaitu semua pendapatan dan keuntungan, biaya dan kerugian yang dilaporkan dalam laba bersih, dan semua keuntungan dan kerugian yang memotong laba bersih tapi mempengaruhi ekuitas.

Penghasilan komprehensif lain (OCI) adalah total penghasilan dikurangi total beban yang tidak ada dalam laba rugi sesuai persyaratan dalam SAK lainnya termasuk penyesuaian reklasifikasi (Adhawati, 2019). Menurut Hans et al. (2012)penghasilan komprehensif lain terdiri atas pos-pos penghasilan dan beban yang tidak diakui dalam laba rugi termasuk penyesuaian reklasifikasi sebagaimana diizinkan oleh SAK. Dalam Pernyataan Standar Akuntansi Keuangan (PSAK) 1 tentang Penyajian Laporan keuangan penghasilan komprehensif didefinisikan sebagai kenaikan kekayaan perusahaan akibat pengaruh berbagai hal yang tidak berhubungan dengan operasi normal perusahaan. Pada paragraf 7 disebutkan bahwa penghasilan komprehensif lain terdiri atas pos-pos penghasilan dan beban yang tidak diakui dalam laba rugi (termasuk penyesuaian reklasifikasi) seperti yang disyaratkan atau diizinkan oleh SAK. Pos ini menampung peningkatan aset yang diakibatkan oleh peningkatan ekuitas, bukan akibat transaksi oleh pemilik (Adias, 2017). Tujuan dari pendapatan komprehensif lain adalah untuk melakukan pelaporan terhadap pengukuran komponen ekuitas suatu perusahaan pada periode tertentu (Ardy, 2016).

Menurut Bahri (2016) penghasilan komprehensif lain adalah perubahan aset atau liabilitas yang tidak berpengaruh terhadap laba rugi periode berjalan misalnya selisih atas revaluasi aset tetap serta pajak penghasilan yang berhubungan dengan selisih revaluasi tersebut dan selisih kurs sebagai akibat penjabaran laporan keuangan dalam mata uang asing. Selanjutnya, menurut Karyawati (2013) pendapatan komprehensif lain adalah keuntungan yang didapatkan perusahaan karena kondisi, bukan karena berusaha. Adhawati (2019) mendefinisikan penghasilan komprehensif lain sebagai total penghasilan dikurangi dengan total beban (termasuk penyesuaian reklasifikasi) yang tidak terdapat dalam laba rugi sebagaimana disyaratkan dalam SAK lainnya.

Penghasilan komprehensif lain merupakan keuntungan atau kerugian yang didapatkan oleh perusahaan di luar aktivitas usaha normal perusahaan. Faktor yang memengaruhi penghasilan komprehensif lain misalnya perubahan nilai wajar, perbedaan nilai tukar (kurs), dan penilaian oleh aktuaris. Penghasilan komprehensif lain dilaporkan sebagai bagian dari laporan laba rugi komprehensif dan diklasifikasikan secara terpisah berdasarkan akunnya. 
Komponen penghasilan komprehensif lain diklasifikasikan secara terpisah berdasarkan akunnya. Berdasarkan PSAK 1 tentang Penyajian Laporan Keuangan komponen penghasilan komprehensif lain mencakup perubahan dalam surplus revaluasi yang mengacu pada PSAK 16 tentang Aset Tetap dan PSAK 19 tentang Aset Tak Berwujud, pengukuran kembali program imbalan pasti yang mengacu pada PSAK 24 tentang Imbalan Kerja, keuntungan dan kerugian yang timbul dari penjabaran laporan keuangan dari kegiatan usaha luar negeri yang mengacu pada PSAK 10 tentang Pengaruh Perubahan Kurs Valuta Asing, keuntungan dan kerugian dari pengukuran kembali aset keuangan sebagai tersedia untuk dijual, dan bagian efektif dari keuntungan dan kerugian instrumen lindung nilai dalam rangka lindung nilai arus kas yang mengacu pada PSAK 55 tentang Instrumen Keuangan: Pengakuan dan Pengukuran (Ikatan Akuntansi Indonesia, 2014).

Menurut Kieso et al. (2018) komponen penghasilan komprehensif lain antara lain: pertama, perubahan terkait surplus revaluasi aset tetap dan aset tak berwujud yaitu selisih antara nilai tercatat dengan nilai yang diukur menggunakan model revaluasi; kedua, keuntungan dan kerugian aktuaria atas program manfaat pasti yang diakui, terdiri dari penyesuaian akibat perbedaan asumsi aktuaria dengan kenyataan dan dampak perubahan asumsi aktuaria; ketiga, keuntungan dan kerugian dari pengukuran kembali aset keuangan yang ditetapkan sebagai tersedia untuk dijual yaitu ketika suatu keuntungan atau kerugian pada suatu pos non moneter diakui dalam pendapatan komprehensif lain, maka setiap komponen perubahan dari keuntungan atau kerugian itu diakui dalam penghasilan komprehensif lain; keempat, bagian efektif dari keuntungan dan kerugian instrumen lindung nilai dalam rangka aktivitas lindung nilai; dan kelima, keuntungan dan kerugian dari pengukuran kembali aset keuangan yang ditetapkan sebagai tersedia untuk dijual berupa selisih antara nilai tercatat aset keuangan tersedia untuk dijual dengan nilai wajarnya pada tanggal pelaporan keuangan yang belum direalisasikan.

\section{METODE PENELITIAN}

Metode yang digunakan dalam penelitian ini adalah menggunakan metode kualitatif dengan teknik analisis isi (content analysis). Analisis isi (content analysis) menurut Gubrium et al. (1992) dalam Somantri (2010) merupakan metode untuk mengkaji sebuah makna menjadi kategori umum dari berbagai macam dokumen. Tujuan analisis isi adalah untuk mendapatkan jawaban untuk pertanyaan tentang dari mana kategori-kategori itu dikembangkan. Mugiyati (2015). Dengan metode ini, data sekunder yang berasal dari laman www.idnfinancials.com diolah dengan tetap mempertahankan keasliannya. Selanjutnya, data yang telah diperoleh tersebut dikumpulkan untuk dilakukan analisis untuk diambil simpulan. Penelitian ini menggunakan data perusahaan sektor jasa keuangan yang terdaftar di Bursa Efek Indonesia (BEI) pada tahun 2012 - 2018. Data perusahaan yang digunakan hanya diambil untuk perusahaan yang memiliki tanggal pencatatan sebelum tahun 2012. Jumlah sampel yang digunakan dalam penelitian ini 34 perusahaan selama 7 tahun yaitu 238 observasi.

\section{HASIL DAN PEMBAHASAN}

\section{Gambaran umum komponen penghasilan komprehensif lain}

Setiap perusahaan tidak selalu melaporkan semua komponen penghasilan komprehensif lain (OCI) di atas. Komponen OCI yang dilaporkan oleh perusahaan juga tidak selalu sama setiap tahunnya. Komponen OCI yang dilaporkan tiap perusahaan pun berbeda antara satu perusahaan dengan perusahaan lain. Sejak tahun 2012 sampai 2018 terdapat 422 komponen OCI yang dilaporkan oleh perusahaan sektor jasa keuangan yang 
terdaftar di Bursa Efek Indonesia. Komponen OCI paling banyak dilaporkan adalah komponen sekuritas tersedia untuk dijual, dengan jumlah 170 (40,28\%). Komponen OCI terbanyak kedua yang dilakukan adalah komponen pengukuran kembali program imbalan pasti dengan jumlah 147 (34,83\%). Komponen OCI selanjutnya adalah perubahan surplus revaluasi aset dengan jumlah 46 (10,90\%). Komponen OCI berikutnya adalah selisih kurs dengan jumlah 35 (8,29\%). Komponen OCI paling sedikit yang dilaporkan adalah lindung nilai dengan jumlah 24 (5,69\%). Dengan demikian, perusahaan sektor jasa keuangan yang terdaftar di Bursa Efek Indonesia tahun 2012-2018 secara umum telah melaporkan komponen OCI sesuai dengan paragraf 7 PSAK 1 tentang penyajian laporan keuangan.

Dari 34 perusahaan sektor jasa keuangan yang terdaftar di Bursa Efek Indonesia selama kurun waktu 2012-2018, komponen sekuritas tersedia untuk dijual disajikan dalam 170 laporan. Dengan kata lain, sebanyak $71,43 \%$ melaporkan komponen ini sedangkan 28,57\% tidak melaporkan komponen ini. Selanjutnya, komponen pengukuran kembali program imbalan pasti disajikan dalam 146 laporan. Dengan kata lain, sebanyak $61,34 \%$ melaporkan dan 38,66\% tidak. Setelah itu, komponen perubahan surplus revaluasi aset disajikan dalam 46 laporan atau dengan kata lain sebanyak 19,33\% melaporkan dan $80,67 \%$ tidak. Sementara itu, komponen selisih kurs disajikan dalam 35 laporan. Dengan demikian, 14,71\% melaporkan dan 85,29\% tidak. Setelah itu, komponen lindung nilai disajikan dalam 24 laporan atau dengan kata lain 10,08\% melaporkan dan $89,92 \%$ tidak.

Berdasarkan data tersebut, kelima komponen OCI menurut PSAK 1 (IAI, 2015), komponen yang paling sering disajikan oleh perusahaan dalam laporan keuangannya adalah komponen keuntungan dan kerugian dari pengukuran kembali aset keuangan sebagai tersedia untuk dijual (sekuritas tersedia untuk dijual) dan komponen pengukuran kembali program imbalan pasti (imbalan kerja). Perusahaan sektor jasa keuangan memiliki aset keuangan yang dikategorikan sebagai aset keuangan tersedia untuk dijual. Dari seluruh komponen penghasilan komprehensif lain yang telah disebutkan di atas, tidak semua perusahaan menyajikan komponen penghasilan komprehensif lain. Komponen imbalan pengukuran kembali program imbalan pasti pernah dilaporkan oleh 34 perusahaan. Oleh karena itu, semua perusahaan sektor jasa keuangan yang terdaftar di Bursa Efek Indonesia pernah melaporkan komponen pengukuran kembali program imbalan pasti dalam laporan penghasilan komprehensif lain. Sementara itu, komponen sekuritas tersedia untuk dijual pernah dilaporkan oleh 28 perusahaan atau sebanyak 82,35\% dari semua perusahaan disektor jasa keuangan. Selanjutnya, komponen perubahan surplus revaluasi aset pernah dilaporkan oleh 23 perusahaan atau sebanyak $67,65 \%$ perusahaan pernah melaporkan komponen ini dalam laporan keuangannya. Setelah itu, komponen lindung nilai dan selisih kurs pernah dilaporkan sebanyak masing-masing oleh lima perusahaan atau sebanyak $14,71 \%$ perusahaan.

Jumlah komponen penghasilan komprehensif lain yang dilaporkan oleh perusahaan sektor jasa keuangan yang terdaftar di Bursa Efek Indonesia berbedabeda setiap tahunnya. Secara umum jumlah laporan komponen penghasilan komprehensif lain fluktuatif namun cenderung meningkat dari tahun 20122018. Penurunan jumlah laporan OCI oleh perusahaan sektor jasa keuangan yang terdaftar di Bursa Efek Indonesia terjadi pada tahun 2013 dan 2017. Secara berturut-turut jumlah laporan komponen penghasilan komprehensif lain yang dilaporkan dari tahun 2012-2018 adalah 
37, 33, 38, 70, 86, 76, dan 82. Pada tahun 2013 terjadi penurunan jumlah laporan sebesar empat komponen atau -10,81\% dari tahun sebelumnya. Setelah itu, pada tahun 2014 terjadi kenaikan jumlah laporan sebanyak lima komponen atau $15,15 \%$ dari tahun sebelumnya. Selanjutnya, pada tahun 2015 terdapat kenaikan jumlah laporan sebanyak 32 komponen atau $84,21 \%$ dari tahun sebelumnya. Kenaikan jumlah laporan yang terjadi pada tahun 2015 ini merupakan kenaikan tertinggi yang terjadi selama kurun waktu 2012-2018. Selanjutnya, pada tahun 2016 terjadi kenaikan jumlah laporan sebanyak enam belas komponen atau 22,86\% dari tahun sebelumnya. Setelah itu, pada tahun 2017 terjadi penurunan jumlah laporan sebanyak sepuluh komponen atau $-11,63 \%$ dari tahun sebelumnya. itu, pada tahun 2018 terjadi kenaikan jumlah laporan sebanyak enam komponen atau $7,89 \%$ dari tahun sebelumnya.

\section{Uraian komponen penghasilan komprehensif lain}

Laporan penghasilan komprehensif lain yang disajikan oleh terdiri dari beberapa komponen. Tiap tahun penyajian masingmasing komponen penghasilan komprehensif lain disajikan dengan proporsi yang berbeda. Pada tahun 2012 dari 37 komponen OCI yang dilaporkan pada tahun itu, 65,57\% (25 laporan) merupakan komponen sekuritas tersedia untuk dijual, selisih kurs sebanyak 13,51\% (lima laporan), pengukuran kembali program imbalan pasti sebanyak 10,81\% (empat laporan), dan lindung nilai sebanyak $8,11 \%$ (tiga laporan). Pada tahun 2012 tidak ada perusahaan yang melaporkan komponen perubahan surplus revaluasi aset.

Sementara itu, pada tahun 2013 dari 33 komponen penghasilan komprehensif lain yang dilaporkan paling banyak adalah komponen sekuritas tersedia untuk dijual yaitu sebanyak $69,70 \%$ (23 laporan). Komponen selisih kurs pada tahun 2013 yang dilaporkan adalah sebanyak $15,15 \%$ (lima laporan). Selanjutnya, komponen lindung nilai yang dilaporkan adalah sebanyak 9,09\% (tiga laporan). Komponen pengukuran kembali program imbalan pasti yang dilaporkan adalah sebanyak 6,06\% (dua laporan). Pada tahun 2013 juga tidak ada perusahaan yang melaporkan komponen perubahan surplus revaluasi aset.

Selanjutnya, pada tahun 2014 dari 38 komponen penghasilan komprehensif lain yang dilaporkan, komponen sekuritas tersedia untuk dijual masih menempati urutan yang paling banyak dilaporkan yaitu mencakup 60,53\% (23 laporan). Komponen pengukuran kembali program imbalan pasti dan selisih kurs memiliki jumlah yang sama yaitu $13,16 \%$ (lima laporan). Setelah itu, komponen lindung nilai yang dilaporkan adalah sebanyak $10,53 \%$ (empat laporan). Sementara itu, komponen paling sedikit yang dilaporkan adalah komponen perubahan surplus revaluasi aset yaitu sebanyak 2,63\% (satu laporan).

Pada tahun 2015 dari tujuh puluh komponen yang dilaporkan pada tahun itu, jumlah komponen OCI yang paling banyak dilaporkan adalah pengukuran kembali program imbalan pasti yaitu sebanyak 48,57\% (34 laporan). Sekuritas tersedia untuk dijual yang dilaporkan mencakup $31,43 \%$ (22 laporan). Selanjutnya, perubahan surplus revaluasi aset yang dilaporkan adalah 8,57\% (enam laporan. Sementara itu, selisih kurs yang dilaporkan adalah 7,14\% (lima laporan). Komponen OCI yang paling sedikit dilaporkan adalah lindung nilai yaitu sebanyak 4,29\% (tiga laporan).

Tahun 2016 dari 86 komponen penghasilan komprehensif lain yang dilaporkan, komponen paling banyak adalah pengukuran kembali program 
imbalan pasti yaitu sebanyak 39,53\% (34 laporan). Sekuritas tersedia untuk dijual yang dilaporkan adalah sebanyak 29,07\% (25 laporan). Perubahan surplus revaluasi aset yang dilaporkan adalah sebanyak 22,09\% (sembilan belas laporan). Selisih kurs yang dilaporkan adalah sebanyak $5,81 \%$ (lima laporan). Lindung nilai yang dilaporkan adalah sebanyak 3,49\% (tiga laporan).

Selanjutnya pada tahun 2017 dari 76 komponen penghasilan komprehensif lain yang dilaporkan, komponen pengukuran kembali program imbalan pasti memiliki jumlah yang paling banyak, yaitu sebanyak 44,74\% (34 laporan). Sekuritas tersedia untuk dijual yang dilaporkan adalah sebanyak 34,21\% (26 laporan). Perubahan surplus revaluasi aset yang dilaporkan adalah sebanyak 9,21\% (tujuh laporan). Selisih kurs Yang dilaporkan adalah 6,58\% (lima laporan). Lindung nilai yang dilaporkan adalah sebanyak 5,26\% (empat laporan).

Selanjutnya, pada tahun 2018 dari 83 komponen penghasilan komprehensif lain yang dilaporkan, komponen pengukuran kembali program imbalan pasti memiliki jumlah yang paling banyak yaitu sebanyak 41,46\% (34 laporan). Setelah itu, sekuritas tersedia untuk dijual yang dilaporkan adalah sebanyak $31,71 \%$ (26 laporan). Sementara itu, perubahan surplus revaluasi aset yang dilaporkan adalah sebanyak $15,85 \%$ (tiga belas laporan). Selanjutnya, selisih kurs yang dilaporkan adalah sebanyak $6,10 \%$ (lima laporan). Komponen yang paling sedikit dilaporkan adalah lindung nilai yaitu sebanyak $4,88 \%$ (empat laporan).

Dengan demikian, dapat diketahui bahwa pada tahun 2015 terdapat perubahan proporsi yang cukup signifikan pada komponen OCI yang dilaporkan perusahaan sektor jasa keuangan yang terdaftar di Bursa Efek Indonesia. Proporsi yang mengalami perubahan cukup signifikan adalah komponen sekuritas tersedia dijual dan komponen pengukuran kembali program imbalan pasti. Sejak tahun 2012 sampai dengan tahun 2014 komponen sekuritas tersedia untuk dijual selalu memiliki proporsi di atas $60 \%$ dari seluruh komponen OCI yang dilaporkan. Akan tetapi pada tahun 2015 proporsi komponen sekuritas untuk dijual mengalami penurunan yang signifikan. Hal tersebut membuat proporsi komponen sekuritas tersedia untuk dijual hanya berkisar antara 29\% hingga 34\%. Disisi lain, komponen pengukuran kembali program imbalan pasti mengalami kenaikan proporsi yang cukup signifikan. Dari tahun 2012 sampai tahun 2014 proporsi komponen pengukuran kembali program imbalan pasti hanya berkisar antara $6 \%$ hingga $13 \%$. Akan tetapi, pada tahun 2015 hingga tahun 2018 proporsi komponen pengukuran kembali program imbalan pasti menjadi sebesar $38 \%$ hingga $48 \%$.

\section{Perkembangan jumlah komponen penghasilan komprehensif lain}

\section{Perubahan dalam surplus revaluasi (PSAK 16: Aset Tetap dan PSAK 19: Aset Tak Berwujud)}

Pada tahun 2012 dan 2013 tidak ada perusahaan sektor jasa keuangan yang melaporkan komponen OCI perubahan surplus revaluasi aset. Selanjutnya, pada tahun 2014 sebanyak 97,06\% perusahaan tidak melaporkan komponen revaluasi aset. Hanya sebanyak 2,94\% perusahaan yang melaporkan komponen revaluasi aset pada tahun 2014. Setelah itu, pada tahun 2015 sebanyak $82,35 \%$ perusahaan tidak melaporkan komponen perubahan surplus revaluasi sedangkan $17,65 \%$ perusahaan melaporkan. Setelah itu, pada tahun 2016 terdapat kenaikan yang cukup signifikan. Sebanyak $55,88 \%$ perusahaan melaporkan komponen perubahan surplus revaluasi sedangkan 44,12\% perusahaan tidak melaporkan. Berikutnya pada tahun 2017 
laporan komponen OCI perubahan surplus revaluasi pada perusahaan sektor jasa keuangan kembali menurun, hanya dilaporkan oleh $20,59 \%$ perusahaan, sedangkan $79,41 \%$ perusahaan tidak melaporkan. Pada tahun 2018 laporan komponen OCI perubahan surplus revaluasi sedikit mengalami kenaikan. Tahun 2018 perusahaan yang melaporkan komponen OCI perubahan surplus revaluasi sebanyak 38,24\% sedangkan $61,76 \%$ tidak melaporkan. Dengan demikian, dapat diartikan bahwa komponen perubahan surplus revaluasi cukup jarang dilaporkan oleh perusahaan sektor jasa keuangan yang terdaftar di Bursa Efek Indonesia tahun 2012-2018. Komponen surplus revaluasi memiliki jumlah laporan tertinggi pada tahun 2016 yaitu dilaporkan sebanyak 55,88\% perusahaan.

Rata-rata jumlah perusahaan yang melaporkan komponen perubahan surplus revaluasi selama tahun 2012-2018 adalah sebanyak tujuh perusahaan. Selanjutnya, rata-rata nominal komponen perubahan surplus revaluasi selama tahun 20122018 adalah senilai Rp19.620.539.233.924,00. Pada tahun 2012 dan 2013 tidak ada perusahaan yang melaporkan komponen perubahan surplus revaluasi dalam laporan keuangannya. Pada tahun 2014 terdapat satu perusahaan yang melaporkan komponen perubahan surplus revaluasi. Total nominal yang dilaporkan pada tahun 2014 adalah Rp131.770.000.000,00. Pada tahun 2015 terdapat enam perusahaan yang melaporkan komponen perubahan surplus revaluasi. Jumlah ini mengalami kenaikan sebanyak $500 \%$ dari tahun sebelumnya. Total nominal yang dilaporkan pada tahun 2015 adalah Rp23.322.982.765.000,00. Selanjutnya, pada tahun 2016 terdapat kenaikan yang cukup signifikan pada jumlah laporan dan total nominal komponen perubahan surplus revaluasi yang dilaporkan. Pada tahun 2016 terdapat sembilan belas perusahaan yang melaporkan komponen perubahan surplus revaluasi. Jumlah ini mengalami kenaikan sebanyak tiga belas perusahaan atau $216,7 \%$ dari tahun sebelumnya. Total nominal yang dilaporkan adalah senilai Rp67.934.711.053.622,00. Tahun 2017 terdapat penurunan jumlah laporan dan total nominal komponen perubahan surplus revaluasi yang dilaporkan. Jumlah laporan pada tahun 2017 menurun sebanyak dua belas laporan atau 63,2\% menjadi tujuh laporan dengan total nominal yang juga menurun sangat signifikan menjadi senilai Rp642.305.345.000,00. Pada tahun 2018 jumlah laporan mengalami kenaikan sebanyak enam laporan atau 85,7\% menjadi tiga belas laporan. Akan tetapi kenaikan ini tidak diikuti dengan kenaikan total nominal yang cukup signifikan yaitu senilai Rp6.070.927.006.000,00.

Berdasarkan uraian di atas dapat diketahui bahwa terdapat kenaikan signifikan yang terjadi pada tahun 2015 dan 2016. Penyebab kenaikan tersebut adalah adanya ketentuan revaluasi aset untuk tujuan perpajakan sesuai Peraturan Menteri Keuangan nomor PMK191/PMK.010/2015 sebagaimana telah diubah dengan Peraturan Menteri Keuangan nomor 29/PMK.03/2016 tentang Penilaian Kembali Aktiva Tetap untuk Tujuan Perpajakan bagi Permohonan yang Diajukan pada Tahun 2015 dan Tahun 2016. Dengan adanya peraturan ini perusahaan mendapatkan insentif berupa penurunan tarif dari $10 \%$ menjadi $3 \%$ sampai $6 \%$.

\section{Pengukuran kembali program imbalan pasti (PSAK 24: Imbalan Kerja)}

Komponen pengukuran kembali program imbalan pasti yang dilaporkan oleh perusahaan jasa keuangan jumlahnya fluktuatif. Pada tahun 2012 sebanyak $88,24 \%$ perusahaan tidak melaporkan komponen pengukuran kembali program imbalan pasti, sedangkan $11,76 \%$ 
perusahaan melaporkan. Sementara itu, pada tahun 2013 persentase perusahaan yang tidak melaporkan komponen pengukuran kembali program imbalan pasti bertambah menjadi sebanyak $94,12 \%$, sedangkan persentase perusahaan yang melaporkan hanya sebesar $5,88 \%$. Selanjutnya, pada tahun 2013 persentase perusahaan yang tidak melaporkan komponen pengukuran kembali program imbalan pasti berkurang menjadi 85,29\%, sedangkan perusahaan yang melaporkan sebanyak $14,71 \%$. Selanjutnya, pada tahun 2015 terjadi kenaikan yang sangat signifikan terhadap persentase perusahaan yang melaporkan komponen pengukuran kembali program imbalan pasti. Pada tahun 2015 hingga tahun 2018 semua perusahaan melaporkan komponen pengukuran kembali program imbalan pasti pada bagian penghasilan komprehensif lain. Fenomena tersebut terjadi karena adanya perubahan PSAK 24 pada tahun 2013 yang mulai berlaku per 1 Januari 2015. Perubahan ini mengharuskan pengakuan keuntungan dan kerugian aktuaria diakui dalam penghasilan komprehensif lain, bukan penambah atau pengurang komponen liabilitas imbalan pasti.

Rata-rata jumlah perusahaan yang melaporkan komponen pengukuran kembali program imbalan pasti selama tahun 2012-2018 adalah sebanyak 21 perusahaan. Selanjutnya, rata-rata nominal komponen pengukuran kembali program imbalan pasti selama tahun 2012-2018 adalah senilai Rp458.871542.431,00. Pada tahun 2012 terdapat empat perusahaan yang melaporkan komponen pengukuran kembali program imbalan pasti. Total nominal yang dilaporkan adalah Rp92.144.000.000,00. Sementara itu, pada tahun 2013 terdapat dua perusahaan yang melaporkan komponen pengukuran kembali program imbalan pasti dengan total nominal senilai Rp55.421.000.000,00. Selanjutnya, pada tahun 2014 terdapat lima perusahaan yang melaporkan komponen pengukuran kembali program imbalan pasti dengan total nominal senilai

Rp73.165.000.000,00. Setelah itu, pada tahun 2015 jumlah perusahaan yang melaporkan komponen pengukuran kembali program imbalan pasti mengalami kenaikan sangat signifikan. Pada tahun 2015 hingga 2018 semua perusahaan melaporkan komponen pengukuran kembali program imbalan pasti. Fenomena ini terjadi karena adanya revisi PSAK 24 pada tahun 2015 yang mulai berlaku untuk laporan keuangan yang dimulai pada atau setelah 1 Januari 2015. Total nominal komponen pengukuran kembali program imbalan pasti yang dilaporkan oleh perusahaan jasa keuangan dari tahun 2015 hingga 2018 berfluktuasi. Pada tahun 2015 total nominal yang dilaporkan mengalami kenaikan dari tahun sebelumnya menjadi senilai Rp1.087.780.398.733,00. Setelah itu, pada tahun 2016 total nominal yang dilaporkan mengalami penurunan dari tahun sebelumnya menjadi senilai Rp225.534.571.361,00. Selanjutnya, pada tahun 2017 total nominal yang dilaporkan mengalami penurunan sangat signifikan hingga bernilai negatif menjadi senilai Rp2.769.746.899.219,00. Setelah itu, pada tahun 2018 total nominal yang dilaporkan mengalami kenaikan paling signifikan menjadi senilai Rp4.889.262.726.144,00.

Dari uraian di atas dapat diketahui bahwa terdapat kenaikan yang sangat signifikan atas jumlah perusahaan yang melaporkan komponen pengukuran kembali program manfaat pasti pada tahun 2015. Setelah berlakunya revisi PSAK 24 untuk tahun buku mulai 1 Januari 2015, perusahaan jasa keuangan yang terdaftar di Bursa Efek Indonesia wajib mengakui adanya keuntungan dan kerugian aktuaria dalam penghasilan komprehensif lain. Sebelumnya adanya revisi PSAK 24 tahun 2013, keuntungan dan kerugian aktuaria sebagai komponen untuk menghitung liabilitas imbalan pasti. 
Keuntungan dan kerugian yang timbul dari penjabaran laporan keuangan dari kegiatan usaha luar negeri (PSAK 10: Pengaruh Perubahan Kurs Valuta Asing)

Selama tahun 2012 hingga 2018 terdapat sebanyak $14,71 \%$ perusahaan yang melaporkan komponen keuntungan dan kerugian yang timbul dari penjabaran laporan keuangan dari kegiatan usaha luar negeri. Dengan demikian, dapat diartikan bahwa proporsi laporan komponen tersebut adalah tetap. Meskipun proporsi pelaporan komponen keuntungan dan kerugian yang timbul dari penjabaran laporan keuangan dari kegiatan usaha luar negeri pada perusahaan sektor jasa keuangan yang terdaftar di Bursa Efek Indonesia tahun 2012-2018 tidak berubah, namun jumlah nominal yang disajikan dalam laporan keuangan mengalami fluktuasi. Rata-rata jumlah perusahaan yang melaporkan komponen keuntungan dan kerugian yang timbul dari penjabaran laporan keuangan dari kegiatan usaha luar negeri selama tahun 20122018 adalah lima perusahaan dengan ratarata nominal komponen tersebut adalah Rp43.655.000.000,00. Jumlah perusahaan yang melaporkan komponen keuntungan dan kerugian yang timbul dari penjabaran laporan keuangan dari kegiatan usaha luar negeri dari tahun 2012 hingga 2018 adalah tetap yaitu sebanyak lima perusahaan. Pada tahun 2012 total nominal yang dilaporkan adalah Rp37.276.000.000,00. Sementara itu, pada tahun 2013 total nominal yang dilaporkan mengalami kenaikan yang sangat signifikan menjadi Rp254.428.000.000,00. Selanjutnya, pada tahun 2014 jumlah nominal yang dilaporkan mengalami penurunan menjadi Rp19.829.000.000,00. Setelah itu, pada tahun 2015 jumlah nominal laporan mengalami kenaikan menjadi Rp99.188.000.000,00. Sementara itu, pada tahun 2016 total nominal yang dilaporkan mengalami penurunan cukup signifikan hingga menjadi -Rp72.804.000.000,00. Selanjutnya, pada tahun 2017 total nominal yang dilaporkan mengalami kenaikan menjadi Rp3.558.000.000,00. Pada tahun 2018 total nominal yang dilaporkan oleh perusahaan sektor keuangan yang terdaftar di Bursa Efek Indonesia mengalami penurunan menjadi Rp35.890.000.000,00. Dengan demikian, dapat diketahui bahwa tidak ada perubahan jumlah perusahaan yang melaporkan komponen keuntungan dan kerugian yang timbul dari penjabaran laporan keuangan dari kegiatan usaha luar negeri dari tahun 2012 hingga 2018.

Keuntungan dan kerugian dari pengukuran kembali aset keuangan sebagai "tersedia untuk dijual" (PSAK 55: Instrumen Keuangan: Pengakuan dan Pengukuran)

Pada tahun 2012 sebanyak 73,53\% perusahaan melaporkan komponen keuntungan dan kerugian dari pengukuran kembali aset keuangan tersedia untuk dijual, sedangkan $26,47 \%$ perusahaan tidak melaporkan komponen ini. Selanjutnya, pada tahun 2013 sebanyak $63,65 \%$ perusahaan melaporkan komponen tersebut sedangkan $32,35 \%$ perusahaan tidak melaporkan. Sementara itu, pada tahun 2014 sebanyak $67,65 \%$ perusahaan melaporkan komponen ini, sedangkan perusahaan yang tidak melaporkan sebanyak $32,35 \%$. Setelah itu, pada tahun 2015 persentase perusahaan yang melaporkan komponen tersebut adalah sebanyak $64,71 \%$, sedangkan perusahaan yang tidak melaporkan adalah sebanyak $35,29 \%$. Selanjutnya, pada tahun 2016 terjadi kenaikan persentase perusahaan yang melaporkan komponen keuntungan dan kerugian dari pengukuran kembali aset keuangan tersedia untuk dijual menjadi $73,53 \%$, sedangkan perusahaan yang tidak melaporkan sebanyak $26,47 \%$. Pada tahun 2017 persentase perusahaan yang melaporkan komponen tersebut adalah $76,47 \%$, sedangkan perusahaan yang tidak melaporkan adalah 23,53\%. Setelah itu, pada tahun 2018 perusahaan yang 
melaporkan komponen tersebut sebanyak $76,47 \%$, sedangkan perusahaan yang tidak melaporkan adalah sebanyak $23,53 \%$.

Dengan demikian, dapat dilihat bahwa proporsi perusahaan yang melaporkan komponen keuntungan dan kerugian dari pengukuran kembali aset keuangan tersedia untuk dijual cenderung stabil dan tidak mengalami fluktuasi yang signifikan. Selain itu, dapat dilihat juga bahwa proporsi pelaporan komponen ini selalu lebih dari $60 \%$ dari total perusahaan sektor jasa keuangan yang terdaftar di Bursa Efek Indonesia tahun 2012-2018.

Nilai wajar suatu aset keuangan mengalami kenaikan dan penurunan dari waktu ke waktu. Oleh karena itu jumlah nominal komponen keuntungan dan kerugian dari pengukuran kembali aset keuangan sebagai tersedia untuk dijual yang dilaporkan mengalami fluktuasi. Di bawah ini merupakan grafik perkembangan jumlah laporan dan nominal komponen keuntungan dan kerugian dari pengukuran kembali aset keuangan sebagai tersedia untuk dijual pada perusahaan sektor jasa keuangan yang terdaftar di Bursa Efek Indonesia tahun 2012-2018. Rata-rata jumlah perusahaan yang melaporkan komponen keuntungan dan kerugian dari pengukuran kembali aset keuangan sebagai tersedia untuk dijual dari tahun 2012 hingga 2018 adalah sebanyak 24 perusahaan. Selain itu, rata-rata nominal yang dilaporkan adalah senilai -Rp1.629.554.360.233. Pada tahun 2012 terdapat 25 perusahaan yang melaporkan komponen keuntungan dan kerugian dari pengukuran kembali aset keuangan sebagai tersedia untuk dijual dengan total nominal senilai Rp1.776.792.437.457,00. Setelah itu, pada tahun 2013 jumlah perusahaan yang melaporkan berkurang menjadi 23 perusahaan dengan total nominal yang menurun cukup signifikan menjadi senilai -Rp11.618.100.344.162,00. Selanjutnya, pada tahun 2014 jumlah perusahaan yang melaporkan sama dengan tahun sebelumnya yaitu sebanyak 23 perusahaan. Total nominal yang dilaporkan pada tahun 2014 mengalami kenaikan menjadi Rp1.776.792.437.457,00. Selanjutnya, pada tahun 2015 terdapat penurunan jumlah perusahaan yang melaporkan menjadi 22 perusahaan, dengan total nominal yang juga menurun menjadi senilai -Rp4.219.159.303.871,00. Setelah itu, pada tahun 2016 jumlah perusahaan yang melaporkan bertambah menjadi 25 perusahaan, dengan total nominal senilai Rp4.407.826.570.895,00. Sementara itu, pada tahun 2017 jumlah perusahaan yang melaporkan kembali bertambah menjadi 26 perusahaan. Total nominal yang dilaporkan pada tahun 2017 mengalami peningkatan cukup signifikan menjadi Rp11.035.534.256.419,00. Pada tahun 2018 jumlah perusahaan yang melaporkan sama dengan tahun sebelumnya yaitu sebanyak 26 perusahaan. Akan tetapi, pada tahun 2018 terjadi penurunan yang sangat signifikan pada total nominal yang dilaporkan menjadi senilai Rp18.370.729.915.149,00.

Dengan demikian, dapat diketahui bahwa jumlah perusahaan yang melaporkan komponen keuntungan dan kerugian dari pengukuran kembali aset keuangan sebagai "tersedia untuk dijual" dari tahun 2012-2018 tidak terlalu banyak mengalami perubahan. Jumlah perusahaan yang melaporkan berkisar antara 22 hingga 26 perusahaan. Akan tetapi jumlah nominal yang dilaporkan oleh perusahaan mengalami fluktuasi dari tahun ke tahun. Jumlah nominal paling tinggi terjadi pada tahun 2017, sedangkan jumlah nominal paling rendah terjadi pada tahun 2018 .

Bagian efektif dari keuntungan dan kerugian instrumen lindung nilai dalam rangka lindung nilai arus kas (PSAK 55: Instrumen Keuangan: Pengakuan dan Pengukuran) 
Proporsi perusahaan yang melaporkan komponen bagian efektif dari keuntungan dan kerugian instrumen lindung nilai dalam rangka lindung nilai arus kas. Pada tahun 2012 dan 2013 persentase perusahaan yang melaporkan adalah sama yaitu sebesar 8,82\% sedangkan 91,18\% persen tidak melaporkan. Setelah itu, pada tahun 2013 persentase perusahaan yang melaporkan naik menjadi $11,76 \%$, sedangkan perusahaan yang tidak melaporkan sebesar 88,24\%. Selanjutnya, pada tahun 2015 dan tahun 2016 persentase perusahaan yang melaporkan kembali turun menjadi $8,82 \%$, sedangkan persentase perusahaan yang tidak melaporkan bertambah menjadi 88,24\%. Pada tahun 2017 dan 2018 persentase perusahaan yang melaporkan kembali bertambah menjadi $11,76 \%$ dan persentase perusahaan yang tidak melaporkan berkurang menjadi 88,24\%. Dengan demikian, dapat dilihat bahwa persentase perusahaan yang melaporkan komponen bagian efektif dari keuntungan dan kerugian instrumen lindung nilai dalam rangka lindung nilai arus kas selama tahun 2012-2018 relatif kecil bila dibandingkan dengan persentase perusahaan yang tidak melaporkan. Rata-rata jumlah perusahaan yang melaporkan komponen bagian efektif dari keuntungan dan kerugian instrumen lindung nilai dalam rangka lindung nilai arus kas dari tahun 2012 hingga 2018 adalah 3 perusahaan dengan rata-rata total nominal yang dilaporkan perusahaan adalah senilai -Rp11.707.630.000,00. Pada tahun 2012 dan 2013 jumlah perusahaan yang melaporkan sama yaitu sebanyak tiga perusahaan. Total nominal yang dilaporkan pada tahun 2012 adalah senilai Rp8.283.000.000,00. Setelah itu, total nominal yang dilaporkan pada tahun 2013 mengalami kenaikan menjadi Rp56.152.000.000,00. Selanjutnya, pada tahun 2014 jumlah perusahaan yang melaporkan bertambah menjadi empat perusahaan. Akan tetapi total nominal yang dilaporkan oleh perusahaan menurun cukup signifikan menjadi -
Rp104.063.509.000,00. Setelah itu, pada tahun 2015 jumlah perusahaan yang melaporkan berkurang menjadi tiga perusahaan, akan tetapi total nominal yang dilaporkan oleh perusahaan meningkat sangat signifikan menjadi Rp240.078.703.000,00. Pada tahun 2016 jumlah perusahaan yang melaporkan sama dengan tahun sebelumnya. Akan tetapi total nominal yang dilaporkan oleh perusahaan kembali mengalami penurunan menjadi senilai -Rp76.199.193.000,00. Selanjutnya, pada tahun 2017 jumlah perusahaan yang melaporkan kembali bertambah menjadi empat perusahaan dengan total nominal yang dilaporkan menjadi -Rp109.292.270.000,00. Pada tahun 2018 jumlah perusahaan yang melaporkan sama dengan tahun sebelumnya yaitu sebanyak empat perusahaan. Total nominal yang dilaporkan oleh perusahaan adalah senilai Rp96.912.141.000,00.

Dari seluruh pembahasan di atas dapat diamati bahwa komponen penghasilan komprehensif lain yang disajikan perusahaan sektor jasa keuangan yang terdaftar di Bursa Efek Indonesia tahun 2012-2018 didominasi oleh dua komponen yaitu sekuritas tersedia untuk dijual dan imbalan pasti. Hal tersebut dapat mengindikasikan bahwa Sebagian besar perusahaan sektor jasa keuangan yang terdaftar di Bursa Efek Indonesia memiliki aset keuangan yang diklasifikasikan sebagai tersedia dijual sehingga dalam setiap akhir periode perlu mengakui keuntungan atau kerugian atas pengukuran kembali aset keuangan ini dan akan dilaporkan dalam penghasilan komprehensif tahun berjalan. Selain itu, perusahaan sektor jasa keuangan telah memenuhi ketentuan undang-undang mengenai imbalan pasca kerja yang setiap tahunnya perlu dinilai kembali dan perubahan estimasi tersebut dilaporkan dalam penghasilan komprehensif lain tahun berjalan. Penyajian komponen penghasilan komprehensif lain dipengaruhi 
oleh banyak faktor baik internal maupun eksternal. Faktor eksternal yang dapat mempengaruhi perusahaan untuk melaporkan komponen penghasilan komprehensif lain misalnya adanya peraturan perundang-undangan, revisi PSAK, dan insentif perpajakan. Jumlah komponen OCI yang dilaporkan oleh perusahaan sektor jasa keuangan dari tahun 2012-2018 secara umum mengalami kenaikan dari tahun ke tahun.

\section{KESIMPULAN DAN SARAN}

Komponen yang paling banyak dilaporkan adalah keuntungan dan kerugian atas pengukuran kembali aset keuangan sebagai 'tersedia untuk dijual' dengan jumlah $170 \quad(40,28 \%)$. Komponen keuntungan dan kerugian atas pengukuran kembali aset keuangan sebagai 'tersedia untuk dijual' selama periode tersebut adalah sebanyak 71,43\%. Komponen pengukuran kembali program imbalan pasti adalah komponen yang selalu dilaporkan oleh setiap perusahaan jasa keuangan selama tahun 2012-2018. Proporsi perusahaan yang melaporkan komponen pengukuran kembali program imbalan pasti mengalami kenaikan yang sangat signifikan pada tahun 2015. Mulai tahun 2015 hingga 2018 semua perusahaan melaporkan komponen ini pada bagian penghasilan komprehensif lain. Kenaikan tersebut karena adanya perubahan PSAK 24 pada tahun 2013 yang mulai berlaku per 1 Januari 2015. Perubahan ini mengharuskan pengakuan keuntungan dan kerugian aktuaria diakui dalam penghasilan komprehensif lain, bukan penambah atau pengurang komponen liabilitas imbalan pasti.

Penelitian ini memiliki keterbatasan karena hanya menggunakan data perusahaan sektor jasa keuangan yang terdaftar di Bursa Efek Indonesia tahun 2012-2018 sebagai data penelitian. Dengan demikian, penelitian ini belum bisa menggambarkan kondisi seluruh perusahaan secara umum di Indonesia setelah adopsi IFRS. Oleh karena itu, penelitian selanjutnya agar dapat menggunakan data sektor lain untuk membandingkan hasil penelitian tersebut dengan penelitian ini. Selain itu, penelitian selanjutnya juga dapat mengamati masingmasing komponen penghasilan komprehensif lain sehingga pembahasan yang dilakukan dapat lebih mendalam dan memperkaya referensi mengenai penghasilan komprehensif lain.

Berdasarkan hasil penelitian ini, komponen penghasilan komprehensif lain dalam laporan keuangan perusahaan sektor jasa keuangan hendaknya disajikan dengan jelas agar mudah dipahami oleh pemangku kepentingan. Dengan demikian, keputusan ekonomis yang diambil oleh pemangku kepentingan menjadi tepat dan kepercayaan pemangku kepentingan terhadap perusahaan sektor jasa keuangan pun akan meningkat. Selain itu, informasi mengenai komponen penghasilan komprehensif lain dapat berguna sebagai pertimbangan investor dalam mengambil keputusan. Oleh karena itu, investor hendaknya lebih cermat dan teliti dalam memahami laporan keuangan terutama pos penghasilan komprehensif lain sebelum mengambil keputusan investasinya. Selanjutnya, penyajian penghasilan komprehensif lain pada laporan keuangan dapat menjadi potensi pendapatan pajak yang dapat dikenakan oleh pemerintah. Oleh karena itu, regulasi yang ditetapkan pun harus dapat mengikuti perkembangan industri karena penghasilan komprehensif lain dipengaruhi oleh faktor eksternal perusahaan seperti nilai wajar yang terus berkembang.

\section{UCAPAN TERIMAKASIH}

Penulis mengucapkan terima kasih kepada Jurusan Akuntansi, Politeknik Keuangan Negara STAN yang telah mendukung publikasi. 


\section{DAFTAR PUSTAKA}

Adhawati, W. D. (2019). Pengaruh Other Comprehensive Income, Subjektivitas dari Other Comprehensive Income, dan Nilai Pasar Terhadap Harga Saham (Pada Perusahaan Properti, Real Estate dan Konstruksi Bangunan yang Terdaftar di Bursa Efek Indonesia Tahun 2013-2017).

Adias, C. B. P. (2017). Analisis Penyajian Other Comperhensive Income pada Industri Keuangan yang Terdaftar di Bursa Efek Indonesia Periode 2012-2016.

Ardy, Y. (2016). Investigasi Penyajian Penghasilan Komprehensif Lain dan Komponennya pada Industri Barang Konsumsi Pasca IFRS (Studi Empiris pada Perusahaan Barang Konsumsi yang Terdaftar di Bursa Efek Indonesia Periode 2012-2015). ESENSI, 19(3), 99-114.

Astuti, E., \& Sulistyowati, N. W. (2017). Adaptasi Fair Value Accounting untuk Instrumen Keuangan: Analisis Kualitatif Konvergensi IFRS Perusahaan Perbankan (hal. 6269). Prosiding Seminar Hasil Penelitian dan Pengabdian Kepada Masyarakat UNIPMA.

Bahri, S. (2016). Pengantar Akuntansi. Dalam CV. ANDI OFFSET.

Baker, R. E., Christensen, T. E., Cottrel, D. M., Rais, K. I., Astono, W., \& Wulandari, E. R. (2012). Akuntansi Keuangan Lanjutan (Perspektif Indonesia) Buku 2. Salemba Empat.

Berita Satu. (2013). Songsong MEA 2015, IAI Imbau IFRS Diterapkan Penuh. https://www.beritasatu.com/ekonom i/100437/songsong-mea-2015-iaiimbau-ifrs-diterapkan-penuh

Biswan, A. T., \& Mahrus, M. L. (2019). Praktik Akuntansi Keuangan Menengah (Buku Satu). PKN STAN Press.

Hans, K., Rosita, S., Merliyana, S., \& Sylvia, V. S. (2012). Akuntansi Keuangan Berdasarkan SAK
Berbasis IFRS. Dalam Salemba Empat.

Ikatan Akuntansi Indonesia. (2014). Standar Akuntansi Keuangan Per Efektif 1 Januari 2015. Ikatan Akuntansi Indonesia.

Karyawati, G. (2013). Akuntansi untuk Non-Akuntan. Gramedia Pustaka Utama.

Kieso, D. E., Weygandt, J. J., \& Warfield, T. D. (2018). Intermediate Accounting IFRS Edition (3 ed.). John Wiley \& Son.

Kurniawan, M. (2017). Pendapatan Komprehensif Lain Perusahaan Sektor Aneka Industri di Indonesia (Nomor 2, hal. 259-274). Jurnal Riset Akuntansi dan Perpajakan JRAP Vo. 4, No. 2.

Mahendra, T., \& Firmansyah, A. (2019). Evaluasi Atas Pengungkapan Transaksi Derivatif Lindung Nilai pada Perusahaan Sub Sektor Perbankan di Indonesia. Dalam Jurnal Akuntansi Berkelanjutan Indonesia (Vol. 2, Nomor 3). Politeknik Keuangan Negara STAN.

Martani, D. (2011). Dampak Implementasi IFRS bagi Perusahaan. BUMN TRACK No. 48 Tahun V Juli 2011, 98-99.

Martani, D., Veronica, S., Wardhani, R., \& Tanudjaya, E. (2016). Akuntansi Keuangan Menengah Berbasis PSAK. Dalam 1. https://doi.org/10.1007/978-3-54031885-9

Mugiyati. (2015). Investasi dalam Bisnis Islam Kontemporer Studi Kasus Implementasi Sukuk di Pasar Modal Bursa Efek Indonesia (BEI) Jakarta [UIN Sunan Ampel Surabaya]. Dalam Phd Thesis. http://ir.obihiro.ac.jp/dspace/handle/ $10322 / 3933$

Mustaip, L. (2015). Analisis Penerapan IFRS Sehubungan dengan Pos Other Comprehensive Income (Studi Kasus pada Perusahaan yang Terdaftar di Bursa Efek Indonesia 
pada 2012 - 2013).

Otoritas Jasa Keuangan, I. A. I. \& I. F. (2016). Otoritas Jasa Keuangan, Ikatan Akuntan Indonesia and IFRS Foundation Joint Statement.

Pardede, T. E. N. (2016). Laporan Keuangaan Sebelum dan Sesudah IFRS (International Financial Reporting Standards). https://dosen.perbanas.id/laporankeuangaan-sebelum-dan-sesudahifrs-international-financialreporting-standards/

Pratiwi, C. W., \& Tesniwati, R. (2013). Pengaruh Penerapan IFRS terhadap Kinerja Bank Melalui Tata Kelola Perbankan yang Baik. Dalam Prosiding PESAT (Vol. 5, hal. 8-9).

Rosyadi, M. A., \& Anggraita, V. (2014). Relevansi Risiko Pengukuran Laba Bersih, Laba Komprehensif dan Laba Nilai Wajar: Studi pada BankBank yang Terdaftar di BEI. Tugas Akhir, Jakarta: Universitas Indonesia.

Santoso, Y. D., Ahmar, N., \& Mulyadi, J. (2017). Penyajian Pendapatan Komprehensif Lain dan Komponennya pada Industri Keuangan. Dalam Liquidity (Vol. 6, Nomor 1, hal. 19-31). https://doi.org/10.32546/lq.v6i1.37

Sidantha, B., Ahmar, N., \& Mulyadi, J. (2018). Penyajian Pendapatan Komprehensif Lain: Investigasi pada Industri Infrastruktur dan Utilitas. Dalam JIAFE (Jurnal Ilmiah Akuntansi Fakultas Ekonomi) (Vol. 2, Nomor 2, hal. 59-71).

https://doi.org/10.34204/jiafe.v2i2.5 44

Somantri, G. (2010). Memahami Metode Kualitatif. Seri Sosial Humaniora (Social Humanities Series); Vol 9, No 2 (2005): Desember, 9. https://doi.org/10.7454/mssh.v9i2.1 22

Suyatmini, \& Sheilla FN, A. (2014). Kajian tentang Konvergensi
International Financial Reporting Standard (IFRS) di Indonesia. Dalam Jurnal Pendidikan Ilmu Sosial (Vol. 24, hal. 79-86).

Wahyu, R. P. S., \& Praptoyo, S. (2014). Penyajian dan Komponen Other Comprehensive Income. Dalam Jurnal Imu \& Riset Akuntansi (Vol. 3, Nomor 12, hal. 1-16). 